\title{
DERRIDA'S CRITIQUE OF HUSSERL AND THE PHILOSOPHY OF PRESENCE
}

David B. Allison*

\begin{abstract}
Now would be the time to reject the myths of inductivity and of the Wesenschau, which are transmitted, as points of honor, from generation

to generation. ...Am I primitively the power to contemplate, a pure look which fixes the things in their

temporal and local place and the essences in an invisible heaven; am
\end{abstract}

I this ray of knowing that would have to arise from nowhere? ${ }^{1}$

SÍNTESE - O autor reexamina a crítica de Derrida à fenomenologia de Husserl de forma a mostrar como a sua coerência estrutural emerge não tanto de uma redução a uma doutrina particular, mas antes das exigências de uma concepção unitária, especificamente impostas pelas determinações epistemológicas e metafísicas da presença.

PALAVRAS-CHAVE - Desconstrução. Derrida. Fenomenologia. Husserl. Presença. Significado.
ABSTRACT - The author reexamines Derrida's critique of Husserl's phenomenology, so as to show how its structural coherency arises not so much from the reduction to a particular doctrine, but rather from the demands of a unitary conception, specifically from the demands imposed by the epistemological and metaphysical determinations of presence.

KEY WORDS - Deconstruction. Derrida. Husserl. Meaning. Phenomenology. Presence.

Doutor. Professor, State University of New York, Stony Brook, EUA.

Maurice Merleau-Ponty, Le Visible et l'invisible (Paris: Editions Gallimard, 1964), Eng. tr., Alphonso Lingis, The Visible and the Invisible (Evanston: Northwestern University Press, 1968). pp. 113-116.

\begin{tabular}{|l|l|l|l|l|l|}
\hline VERITAS & Porto Alegre & v. 50 & n. 1 & Março 2005 & p. 89-99 \\
\hline
\end{tabular}


It is practically a truism to say that most of Husserl's commentators have insisted on the rigorously systematic character of his writings. Despite the modifications that his "new beginnings" continually introduced, most critics sought to explain the formally coherent development of Husserl's work by appealing to a principal theme or problematic. Usually, the purpose of these attempts was not so much to evoke a hidden architectonic of concepts as to stress a productive axis of investigation within the widely divergent subject matter of Husserl's meditations. Most often, however, this approach resulted in the elevation of particular doctrines, each valued according to the interest of the respective scholar. Thus, Husserl's task of truly philosophical thinking became transformed into what Eugen Fink has called a series of "symptoms," and the complete work was judged according to Husserl's so-called "doctrine" of the moment. Moreover, the number of historical "influences" to which his thought was claimed to have been indebted also assumed epidemic proportions. Critical access to Husserl's thought, therefore, has focused upon the explicit themes or doctrines of cognition, the ego, intersubjectivity, ontology, constitution, logic, reduction, ideality, and embodiment - not to speak of Husserl's Cartesianism, empiricism, or his indebtedness to Frege and Wundt.

With the publication of Jacques Derrida's La Voix et le phénomène, ${ }^{3}$ however, Husserlian scholarship underwent a dramatic revision. ${ }^{4}$ In that and several adjoining texts, ${ }^{5}$ Derrida argued that the systematic development of Husserl's phenomenology was best demonstrated not in terms of a particular problem, but by the examination of a certain prejudice - namely, the epistemological and metaphysical value of presence - a prejudice that guided the formulation of Husserl's entire work. ${ }^{6}$ Derrida contends that Husserl's account of consciousness, subjectivity, objectivity, constitution, evidence, and logic implicitly or explicitly draw massively upon this unexamined prejudice.

2 Eugen Fink, "Les Concepts opératoires dans la phénoménologie de Husserl," in HUSSERL: Les cahiers de Royaumont, Philosophie No. III, ed. M.-A. Bera (Paris: Éditions de Minuit, 1959), p. 214.

Jacques Derrida, La Voix et le phénomène (Paris: Presses Universitaires de France, 1967), Eng. tr., David B. Allison, Speech and Phenomena (Evanston: Northwestern University Press, 1973).

4 The response was immediate. See. e.g., Emmanuel Levinas, "Tout Autrement," in L'Arc: Jacques Derrida, No. 54 (1973), pp. 33-37, Gérard Granel, "Jacques Derrida et la rature de l'origine," in Critique, Vol. XXII, No. 246 (Nov., 1967), pp. 887-905, Jean Catesson, "A propos d'une pensée de l'intervalle," in Revue de la Métaphysique et de la Morale, No. 1 (1969), pp. 74-90, and Maurice Corvez, "les nouveaux structuralistes," in Revue Philosophique de Louvain, Vol. 67 (Series III), No. 96 (Nov., 1969), pp. 582-605.

5 See. esp., Jacques Derrida, Introduction to the French edition of Edmund Husserl, L'Origine de la Géométrie (Paris: Presses Universitaires de France, 1962), pp. 3-171; Eng tr., John P. Leavey, Edmuund Husserl's The Origin of Geometry: An Introduction (Stony Brook: Nicholas Hays, Ltd., 1978), pp. 23-153. Also, Jacques Derrida, De la Grammatologie (Paris: Ed. de Minuit, 1967), Eng. tr., Gayatri Chakravorty Spivak, Of Grammatology (Baltimore: The Johns Hopkins University Press, 1974), and Jacques Derrida, L'Ecriture et la différence (Paris: Éditions du Seuil, 1967), Eng. tr., Alan Bass, Writing and Difference (Chicago: The University of Chicago Press, 1978).

6 Merleau-Ponty had earlier made an extended criticism of the role presence played in Husserl's thought; especially in The Visible and the Invisible. See particularly, Ch. 3, "Interrogation and Intuition," pp. 105-129 
For Derrida, the structural coherency of Husserlian phenomenology arises not from the reduction to a particular "doctrine", but rather, from the demands of a unitary conception, specifically from the demands imposed by the epistemological and metaphysical determinations of presence. Precisely what this value of presence consists in, how it operates as an axiomatic prejudice within his philosophical system, and what the consequences it entails for Husserlian phenomenology are the subject matter of his general critique.

Derrida argues three basic claims in Speech and Phenomena. The first is that temporal presence in fact serves as the underlying axiom in Husserl's doctrine of signification - as set forth in his Logical Investigations, "Investigation 1: Expression and Meaning."7 Derrida's second claim is that Husserl's subsequent reflections on ideality, consciousness, and objectivity continually draw upon the "essential distinctions" that he established for signification in the First Logical Investigation. Hence, the necessity for Derrida's stress upon this early text. Third, and more generally, Derrida maintains that the axiom of presence has in one way or another determined the various accounts of being, truth, and language, not only for Husserl and phenomenology, but for the broader tradition of Western philosophy as such.

In choosing to begin with a critique of the Logical Investigations, Derrida has selected perhaps the most important, if not the most influential, of Husserl's writings on language. Derrida's interpretation is striking because he claims that the whole of phenomenololgy is implied in a reflection on language, that a discussion of meaning, expression, grammar, and logic - the themes of the Investigations will anticipate and later decide the forthcoming "transcendental" problems. The value of focusing the analysis here lies in the fact that Husserl begins the Investigations with a set of "essential distinctions," a group of operative concepts that will rigorously and systematically guide his thought to the end.

Derrida stresses the importance of these "essential distinctions," not only because they dictate the course and structural unity of Husserl's own work, but because they repeat, in an explicit and cogent way, the very axioms of traditional metaphysics. This is only one stage of the argument, however, for he does not mean to portray Husserl and phenomenology as merely another example in the history of metaphysics. Derrida will argue even more emphatically that Husserl's thought is precisely the paradigm, the highest and final case, of this tradition. And it is ultimately the claims and pretensions of this tradition - the parameters of which are admittedly vast - that Derrida wants to contest.

Derrida asserts that throughout his writings Husserl continually invokes the most conventional concepts of Western metaphysics to serve as the axiomatic foundation for phenomenology, and this is evident from the first "essential distinction." By this procedure a certain decision is made to interpret the sense of being

Edmund Husserl, Logische Untersuchungen, 1st ed., 2 Vols. (Halle: Max Niemeyer, 1900; 2nd ed., 1913). Eng. tr., J.N. Findlay, Logical Investigations, 2 Vols. (New York: Humanities Press, 1970). 
in a particular way. ${ }^{8}$ For Husserl and the tradition, Derrida argues, the sense of being has always been interpreted as presence, and this interpretation assumes two forms: something is insofar as it presents itself or is capable of presenting itself to a subject - as the present object (ob-jectum) of a sensible intuition, or as an objectivity presented to thought. Second, we say that a subject (sub-jectum), or self in general, is only insofar as it is self-present, present to itself in the immediacy of a conscious act. The former sense marks the interpretation of being as objectivity (ousia, physis, etc.), the latter as subjectivity (parousia, nous, etc.). The interpretation of being as presence and self-presence ${ }^{9}$ entails a series of philosophical consequences and conceptual oppositions that persists to the present day, and nowhere are these consequences more strikingly evident than in the thought of Husserl. As part of his critical project of deconstruction, ${ }^{10}$ Derrida discusses the

8 Derrida follows Heidegger's distinction between (a) the sense of Being, (b) the word Being, and (c) the concept of Being. For Heidegger's discussion of this, see Martin Heidegger, Sein und Zeit, 12th ed. (Tübingen: Max Niemeyer, 1972), English translation, John Macquarrie and Edward Robinson, Being and Time (New York: Harper \& Row, 1972), pp. 19-31.

9 This is not to suggest that Husserl or phenomenological thinkers, generally, confuse the distinction between presence and self-presence. This is perhaps the most fundamental dissociation of Heidegger's text, Hegel's Concept of Experience. For Aristotle, "There is a science (episteme) which takes up the theory (theorein) of being (on) and what 'to be' means, taken by itself (auto) (Metaphysics, 1003a21ff., Eng. tr., Richard Hope, New York, Columbia University Press, 1952). Following Heidegger's etymology and interpretation of the relevant Greek terms, that same passage, together with the following brief commentary, reads as follows: "Philosophy 'looks at what is present insofar as it is present and so (looks at) what already prevails in it from itself.' ... Philosophy contemplates what is present, in its presence. Contemplation regards what is present, and strives to regard it only as such." Heidegger then contrasts Hegel's appreciation for the modern period of subjectivity, i.e., parousia. He quotes Hegel (WW, XV, p. 328): "Only now do we in fact arrive at the philosophy of the modern world, and we begin it with Descartes. With him we in fact enter into an independent product of reason, and that the consciousness of self, self-consciousness, is an essential moment of truth. Here, we may say, we are at home; here, like the sailor at the end of his long voyage on the stormy seas, we may cry 'Land!'... In this new period the principle is thinking, thinking proceeding from itself." Heidegger adds the following remark: "Thinking seeks its fundamentum absolutum in its own unshakable certainty of what it has thought. The land in which philosophy has since then made itself at home is the unconditional self-certainty of knowledge." (Hegel's Concept of Experience, Eng. tr., Kenley Royce Dove, New York: Harper \& Row, 1970, pp. 27-28.)

10 The term "deconstruction" (déconstruction) signifies a project of critical thought whose task is to locate, articulate, and "take apart" those concepts which serve as the axioms or rules for a period of thought, those concepts which command the unfolding of an entire epoch of metaphysics. "Deconstruction" is somewhat less negative than the Heideggerian or Nietzschean terms "destruction" or "reversal". It suggests that certain foundational concepts of metaphysics will never be entirely eliminated, even if their importance may seem to be effectively diminished. There is no simple "overcoming" of metaphysics or the language of metaphysics.

In response to a question posed by Jan Kott, Derrida remarks: "Here or there I have used the word déconstruction, which has nothing to do with destruction. That is to say, it is simply a question of (and this is a necessity of criticism in the classical sense of the word) being alert to the implications, to the historical sedimentation of the language we use - and that is not destruction." The discussion appears in The Languages of Criticism and the Sciences of Man: the Structuralist Controversy, ed. Richard Macksey and Eugenio Donato (Baltimore: The Johns Hopkins University Press, 1970), p. 271.

Derrida recognizes, nonetheless, that the system of Western thought is finite. It has a finite number of axioms and a finite number of permutations that will continue to work themselves out in a given period of time as particular moments within this tradition, e.g., as particular schools or movements 
genesis and derivation of this series as it functions in phenomenology. Among the many conceptual oppositions to be found there are those of matter (hyle) and form (eidos, idea), corporeal and incorporeal, body and soul, animate and inanimate, signifier and signified. ${ }^{11}$

Far from being "presuppositionless," therefore, the interpretation of being as presence will provide phenomenology with its axial concepts. The highest principle of phenomenology, apodictic evidence, is precisely a call for the presentation or bringing forth (e-videre) of objects to an immediate and self-present intuition. The notion of transcendental consciousness, as well, is nothing more than the immediate self-presence of this waking life, the realm of what is primordially "my own." By contrast, the concepts of empirical, worldly, corporeal, etc., stand opposed to this realm of self-present ownness. They constitute the sphere of otherness, the mediated, what is different from self-present conscious life, etc. All these concepts find their systematic unity in Husserl's account of language.

Language, for Husserl, serves scientific thought and finds its model in the highest degree of scientific objectivity, the form of logical predication. And, we should not forget, it is across and through language that meaningful statements can be recorded and transmitted, that a body of doctrine can be set down and verified, that a community of scientists can communicate, that science itself becomes possible. Meaningful language, consequently, has its own rules and purpose; it is a "pure logical grammar," and it expresses meanings in predicative form, i.e., in the form of a possible reference to an object. This is where Husserl makes the first "essential distinction" of the Logical Investigations. In language, there are two different sorts of signification: indication and expression. For Husserl, however, only one of these - expression - is meaningful. Expression alone, properly speaking, bears sense.

It is important to understand why Derrida seizes upon this distinction. Meaningful language is limited to expression. But how does expression differ from indication? Husserl understands indication to be a movement of empirical association. One sensible sign stands for something else: a mark, a note, an object makes us pass from something present to thought to something that is only anticipated or expected. There is no meaning content present in indication, there is only an empty signifier and nothing that is signified. That is yet to come, it is yet to be

of philosophy. In this sense, Derrida also speaks of the "completion" of metaphysics, the terminal point of "closure" (clôture) for the system; see Of Grammatology, op. cit., pp. 4-5. But the work of deconstruction does not consist in just pointing out the structural limits of metaphysics. Rather, in breaking down and disassembling the ground of this tradition, its task is both to exhibit the source of paradox and contradiction within the system, within the very axioms themselves, and to set forth the possibilities for a new kind of meditation, one no longer founded on the metaphysics of presence. See also, Philipe Boyer, "Déconstruction: le désire à la lettre," in Change: la destruction, Vol. I, no. 2 (1969), pp. 127-148.

${ }^{11}$ Here Derrida very closely follows the remarks made by Nietzsche, in his work of 1886, Beyond Good and Evil, especially in Part One, "On the Prejudices of Philosophers," and strikingly so in paragraph 20 of Part One. For an account of Nietzsche's analysis of these issues, see David B. Allison, Reading the New Nietzsche (Lanham: Rowman \& Littlefield, 2001), pp. 82-83. 
presented. An expression, however, carries a meaning content with it. Meaning is present as the signified content of expression. What is perhaps more remote, but what for Husserl will ensure the very possibility of meaningful language, is its foundation upon an interpretation of being as presence. Derrida argues not only that this account of language and meaning is impossible, but that it is essentially contradictory, given the conceptual framework of the metaphysics of presence.

For Husserl, the meaning content of expression is ideal. An expression is composed of an explicit, willed meaning intention that "animates" a nonsensible signifier, e.g., the "thought" or "imagined" word, the mere "form" of the actually uttered or written sign. In animating this purely formal signifier, the sign becomes invested with meaning, and meaning (Bedeutung) is ultimately the content of an interpretation (Deutung), while the sign or signifier in general is always a sign of or for something. Now, for Husserl, all these elements of expression are nonreal because they all take place within the immediacy of a self-present consciousness what in the Logical Investigations he calls the sphere of "solitary mental life," and what he will later call transcendental consciousness.

The difficulty in such a conception - and Husserl realizes this - is that actual communication always involves an abandonment of this privileged sphere. It involves the going-out into a world, into a realm of empirical fact. For this reason he maintains that expression is necessarily "interwoven" with indication in every case of effective communication. Husserl must preserve the distinction between the two kinds of sign, however, if he is to retain the ideal status of meaning, the possibility of a purely present and complete meaning. The original distinction is possible, in turn, only if expression can effectively take place within the purity of "solitary mental life." Communication, then, would be a re-presentation of what primordially occurs in this inner sphere. What is "meant" in communication is merely "indicated" by means of sensible signs, by the actually spoken or written signs. The problem for Husserl lies in the relation between expression and indication. What is the nature of this "interweaving"? If there is to be pure expression at all - and, consequently, pure meaning - it must take place wholly within the internal sphere, independently of indication: it would be a "silent" monologue. There could be no meaningful communication per se in such a case, and following Husserl's account, communication would come at the expense of meaning. But if indication were not merely "interwoven" with expression, if it were shown to be absolutely necessary to the very concept of expression, then the initial possibility of their distinction itself becomes suspect. And it is just this very distinction that Derrida contests, together with the terms it rests upon, i.e., "solitary mental life" and purely ideal, self-present meaning.

Derrida first devotes a long critique to Husserl's account of ideality. He insists that an ideal meaning is never a pure presentation to begin with; rather, it is already a re-presentation (Husserl uses the term Vorstellung) to consciousness, it is a product that is constituted across a series of discrete acts. What constitutes the ideality of meaning for Husserl is the possibility of its being repeated an infinite number of times. Clearly, this is never completed; its completion would demand 
our disappearance as finite subjects. In any event, the ideal involves a relation of identity between acts, between a present act and an act that lies outside present consciousness. Moreover, the very form of the signifier, the sensory contour of a word or sign, is itself a constituted historical product. The signifier is neither accidental nor idiomatic; it always reflects a definite linguistic origin and heritage. In addition, each occasion of its use represents (Repräsentation) only one instance of its many possible uses; each use selectively repeats a pre-existent convention. And what is it, finally, that really happens in this "interior monologue," in this expression of "solitary mental life"? The expression is not a communication, for there is nothing to communicate: meaning is immediately self-present to the subject so there is no need to communicate. What kind of expression is this if there is no need to communicate anything to anyone? Husserl says this pure expression takes place entirely in the imagination. The interior monologue, then, is a phantasy representation (Phantasievorstellung, Vergegenwärtigung). But Derrida reminds us that, for Husserl, the imagination can never be purely "neutral"; it is always the modification of an antecedent experience, and its positional character always testifies to an origin in empirical reality. ${ }^{12}$ No matter how it is modified, reality becomes represented in the imagination. The imagination, and consequently, the expressive monologue, is fraught with all those elements Husserl sought to exclude from it, all those empirical references which enter in under the various headings of repetition and representation. From the very start then, language must be just this: a structure of repetition and representation. There can be no refuge from empirical determination in such a structure.

Derrida's critique entails two consequences for Husserl's theory of language: there can be no purely "ideal" meaning, no pure presence of ideality, for at every moment ideality would have to depend on precisely what is nonpresent, what is only repeated and represented in another presence. There can be no sphere of pure self-presence either, for in the simplest act of signifying, "solitary mental life" would be fractured by all that lies outside it, namely, the world. Once this occurs, the distinction between indication and expression can no longer be maintained. There is no presence of self-presence for signification, there is only an endless series of reverberations. What "presents" itself in language is the representation of nonpresence, what Derrida calls "otherness," "difference," or "alterity."13

Speech and Phenomena, op. cit., p. 55.

The theme of difference appears in many forms throughout Derrida's extensive critique of Husserl. He argues that Husserl was too inattentive to the constitutive value of difference, i.e., of spatial, temporal, personal, and logical nonidentity. Most pointedly, Derrida focuses on the problems raised by difference with regard to Husserl's distinction between inner and outer - transcendental and empirical - as well as the role of repetition and representation in the constitution of linguistic and ideal objectivities, and perhaps most tellingly, the problems raised by difference in Husserl's understanding of temporality. Derrida goes on to discuss the concept of difference as it relates to the areas of semiotics, epistemology, and ontology, among others. Each of these uses finds its origin in the more primordial movement of what Derrida terms "differance" (with an a). Derrida derives this neologism from the French "différence." As in the Latin "differre," the French "différer" bears two quite distinct significations. One has a reference to spatiality, as the English "to differ" - to be at 
The distinction between indication and expression seems to be of questionable worth, Derrida contends, once the important function of representation and repetition is made clear. But in carrying out the critical task of deconstruction, Derrida shows how Husserl's whole theory of language is undermined by a still more fundamental problem - one that leads back to the phenomenological form of experience itself - the problem of time. Husserl claimed there was no need for communication in the "interior monologue" because, among other reasons, it took place in an "instant," in the "blink of an eye." Following this account, meaning would be immediately present in the self-same moment. There would be no need to mediate its presentation by means of indicative signs. There would be no temporal distention in this process because signifier and signified are united in a punctual "now."

By Husserl's own premises, however, such an argument must fail. His theory of time dictates against any "punctually isolated" moment, for time is a "phasing," a continual movement of protentional and retentional traces. In The Phenomenology of Internal Time-Consciousness, ${ }^{14}$ Husserl argues that the present necessarily includes the phases of past and future under the heading of retention and protention. This conception of time denies the possiblity of a temporally isolated "moment" or "instant." The very presence of the present is conditioned by what is absent or not yet realized. Far from being the point of origin for constitution, the "present" is itself constituted, produced, and derived from a more primordial source of nonpresence. Again, Derrida finds no arche of presence or self-presence. What he does find is a groundless play of differences that reflects an "outsided and beyond" of past and future. ${ }^{15}$

Derrida invokes the later account of temporality not merely to play upon an inconsistency within Husserl's own thought, but rather to exhibit something far more important. In the Logical Investigations and elsewhere, the very concept of life had been understood as immediate self-presence, as the "living presence" of self-conscious thought. The historical importance of this concept cannot be overstated; it characterizes the modern thought of subjectivity since Descartes. Husserl, however, became increasingly skeptical of this view, as can be seen in his arguments against Brentano in The Phenomenology of Internal Time-

variance, to be unlike, apart, dissimilar, distinct in nature or quality from something. This is even more evident in its cognate form, "to differentiate." The other signification has a reference to temporality, as in the English "to defer" - to put off action to a future time, to delay or postpone. While Derrida briefly explains this term in the first paragraph of Chapter 7 of Speech and Phenomena, he devotes an article of considerable length and importance to it somewhat later on, which is included as an appendix to the English translation of Speech and Phenomena, pp. 129-60.

14 Edmund Husserl, Vorlesungen zur Phanomenologie des inneren Zeitbewusstseins, ed. Martin Heidegger (Halle: Niemeyer, 1929). The Phenomenology of Internal Time-Consciousness, Eng. tr., James S. Churchill (Bloomington: The Indiana University Press, 1964).

15 Speech and Phenomena, esp. pp. 82-87. 
Consciousness, against Hume in Erste Philosophie, ${ }^{16}$ and all throughout his later works, up to and including The Origin of Geometry. He came to see that if the present "now" were conceived as a punctual instant, there could be no coherent account of experience as such. One would paradoxically end in denying the identity of one's own experience, one's own self, as did Hume. There could be no selfrelation in such a case, and in short, there could be no life, understood as absolute subjectivity.

Derrida concludes that the whole problem and history of language must be entirely rethought. Instead of trying to capture and retain a pure presence, we must conceive signification from the start as a movement away from selfpresence, a movement away from the pure presence of a discrete origin and the ideal presence of an identical meaning content. ${ }^{17}$ As a movement of differance, signification precedes and gives rise to the very concepts of self, presence, and meaning. The proper account of signification begins not with the present and fulfilled meaning content, but with the sense that remains to be assembled and built up across the itinerary of convention and practice. Following the work of Ferdinand de Saussure, Derrida maintains that linguistic meaning is not so much the product of an explicit meaning intention as it is the arbitrary configuration of differences between signs. Meaning derives from the distance that extends between one particular sign and the system of other signs in linguistic use. It is this differential character of signs which must first be reckoned with, and this results from conventions existing within language - it is not a matter of meaning intentions that supervene from without. There is no meaning, no signified content, that stands above and is free from this play of differences. Nor could meaning withstand the continuous shifting of differences, the continuous sedimenting of traces, as some ideal identity. For Derrida, there is only a likeness or sameness to meaning, which is constituted across the history of ever-changing usage. Absolute objectivity, therefore, could never be claimed for meaning (yet for Husserl, the highest degree of objectivity is that of absolute ideality: the perfect identity of an omnitemporal meaning). ${ }^{18}$

What is striking in Derrida's claim is the objection that linguistic meaning can never be completely present, either in itself or as the content of consciousness. There can never be an absolutely signified content, an absolutely identical or uni-

${ }_{16}$ Edmund Husserl, ERSTE PHILOSOPHIE (1923-24), Erster Teil: Kritische Ideengeschichte, ed. Rudolf Boehm (The Hague: Martinus Nijhoff, 1956). This is to be found in Vol. VII of Husserliana, Gesammelte Werke.

17 Derrida calls such a move, "decentering." See Jacques Derrida, "Structure, Sign, and Play in the Discourses of the Human Sciences," in The language of Criticism and the Sciences of Man, op. cit., pp. 247-72. This is also to be found in Writing and Difference, op. cit., pp. 278-93.

18 Derrida presents a clear account of this in his essay, "White Mythololgy: Metaphor in the Text of Philosophy," in Margins of Philosophy (Chicago: The University of Chicago Press, 1982), pp. 207-71. The argument draws extensively on Nietzsche's early essay of 1873, "On Truth and Lie in a Nonmoral Sense." See Friedrich Nietzsche, Philosophy and Truth: Selections from Nietzsche's Notebooks of the Early 1870's, Eng. tr. and ed., Daniel Breazeale (Atlantic Highlands: Humanities Press, 1979), pp. 79-97. 
vocal meaning in language. ${ }^{19}$ All these values are denied to meaning once we admit its dependence upon nonpresent elements. Meaning can never be isolated or held in abstraction from its context, e.g., its linguistic, semiotic, or historical context. Each such context is itself a system of reference, a system of signifiers, whose function and reality point beyond the present. What is signified in the present, then, necessarily refers to the differentiating and nonpresent system of signifiers in its very meaning. We can only assemble and recall the traces of what went before: we stand within language, not outside it.

Starting out with the metaphor of "presence," philosophy has generated a system of concepts whose import can be seen as essentially theological, what Heidegger has called the tradition of "onto-theo-logy." ${ }^{20}$ Ontology and theology are fundamentally united in their insistence upon a common ground and universal acount of being, a first cause and final reason to things. For the tradition of Western metaphysics, this unity has always been asserted under the title of an absolute and nonempirical reality, a transcendent being or principle that would subtend the empirical order by virtue of its role as cause and form, arche or telos. What was traditionally held to invest the world with order and substance is ultimately something transcendent to that order: the Divine, the One, the principle of intelligibility, the unconditioned.

Now it is precisely this kind of theololgical status that the concept of meaning - interpreted as ideality or absolute identity - has enjoyed in the history of Western thought, and particularly when the account turns to problems of knowledge and signification. Despite the impurity of language and communication, the possibility of an ideal and identical meaning has always been held out, whether as pure "form," "eidos," "idea," "ideal," or as absolute referent in the form of an ideal content of signification, what Derrida elsewhere calls a "transcendental signified." ${ }^{21}$

Thus, for Husserl, what is "impure" in language is only the adjunction of "the sensory or so to speak bodily" aspect, i.e., the factually uttered phrase, the actually written complex. The "purity" of language, the very possibility of meaningful language, lies outside this sphere in the nonempirical or ideal sphere of meaning, in what can be purely "meant" or "intended" by language, in what can be "ex-

19 Derrida's argument thus denies one of Husserl's main theses in the Logical Investigations (as well as in Formal and Transcendental Logic and "The Origin of Geometry"), i.e., that a critical theory of language can fix ideal and identical meanings as the foundation for strict scientific investigation. Like Wittgenstein of the Philosophical Investigations and Zettel, Derrida argues strongly against the possibility of univocal meaning, a meaning that could endure the continual "shiftings of sense" and emerge as a permanent monument of context-free intelligibility. For Derrida, meaning is essentially "transposition," "transfer," "metaphor," "decentering," etc., and that it is always subject to a pregiven semantic universe.

${ }^{20}$ For an account of this, see especially Martin Heidegger, "Die Onto-Theo-Logische Verfassung der Metaphysik," in Identität und Differenz (Pfullingen: Neske, 1957), Eng. tr., Joan Stambaugh, Identity and Difference (New York: Harper \& Row, 1969), pp. 42-76.

${ }^{21}$ See Jacques Derrida, "Sémiologie et grammatologie: entretien avec Julia Kristeva," in Positions (Paris: Ed. de Minuit, 1972), pp. 25-50. Eng. tr., Alan Bass, Positions (Chicago: The University of Chicago Press, 1972), pp. 14-36. See also, Jacques Derrida, "Linguistics and Grammatology," in Of Grammatology, Part I, ch. 3, pp. 27-73. 
pressed" by language. ${ }^{22}$ But Derrida's reflection leads us to conclude that these distinctions can no longer be claimed for language for the precise reason that there can be no expression without indication, no signified without the signifier, no meaning or sense without the factually constituted complex of signifiers. To conclude that expression can never be "reduced" to an absolutely objective core of meaning, to conclude that meaning itself is no longer conceivable as a purely ideal presence, is also to conclude, for Derrida, that a certain period of metaphysical thought has come to a close.

22 In order to protect the pure presence of both solitary mental life and the signified meaning, a "medium" of signification is required that would be free from all empirical resistance: a signifying "element" is needed that would be absolutely nonempirical. Derrida demonstrates that, for Husserl, this "medium" or "element" is the voice (and however silent it may be, this internal monologue is still "spoken"), and this for two reasons: (1) the voice is the most "ideal" signifying medium in that it appears to be completely free of any empirical substance. (2) Only in speech does the signifier seem to be completely "reduced" to its signified content. The spoken word appears as a strangely diaphaneous and transparent medium for meaning. Because it animates a purely formal signifier (the "sensory contour" of the phoneme - not the actually uttered sound complex itself), the silent speech stands as a pure phenomenon - what Derrida terms "the phenomenological voice."

The importance of the voice is not fortuitous with Husserl: implicitly or explicitly, the vocal medium has always functioned as the highest, the purest, form of signification. Its primacy is also that of reason and thought. How this complicity operates for Husserl and the tradition is one of the major themes of Derrida's general critique. For Derrida, however, the primacy of speech - which is ultimately the primacy of presence - is illusory: it seems primary because it takes place "in an instant," in the apparent absence of the world. But in reality, speech is only possible because a certain kind of "writing" precedes it: namely, the invisible and unconscious inscription of signifying traces, the nonpresent and generative movement of differance that constitutes the system of language itself. And it is precisely on this note that Derrida concludes his essay, "Linguistics and Grammatology": [The] reference to the meaning of a signified thinkable and possible outside of all signifiers remains dependent upon the onto-theo-teleology that I have just evoked. It is thus the idea of the sign that must be deconstructed through a meditation upon writing which would merge, as it must, with the undoing [sollicitation] of onto-theo-logy, faithfully repeating it in its totality and making it insecure in its most assured evidences. One is necessarily led to this from the moment that the trace affects the totality of the sign in both its faces. That the signified is originally and essentially... trace, that it is always already in the position of the signifier, is the apparently innocent proposition within which the metaphysics of the logos, of presence and consciousness, must reflect upon writing as its death and its resource" (Of Grammatology, p. 73). 